\title{
Effects of Ownership Structure on the Performance of Listed Companies on the Ghana Stock Exchange
}

\author{
Alexander Owiredu \\ Department of Accountancy, School of Business \\ Pentecost University College, Ghana \\ Moses Oppong \\ Department of Accountancy, School of Business \\ Pentecost University College, Ghana \\ Ransford Q. Churchill \\ Department of Accountancy, \\ School of Business and Management Studies. Accra Polytechnic, Ghana \\ ransfordchurchill@yahoo.co.uk
}

\begin{abstract}
Every business organisation has an important decision of making returns. This decision also affects its capital base and the decision of either going for equity financing or debt financing. The stock markets are widely viewed as important, if not essential, for the functioning of modern capitalist economies. In Ghana, a huge gap exists in literature on the impact of ownership structure and a firm performance as well as the measure of ownership structure and whether or not the endogeneity of ownership structure affect performances of firms. This paper therefore sought to determine the relationship between the ownership structure of listed firms and performance on Stock Market. The paper made used of secondary data and the data were analyzed using Pearson's Product Moment Correlation and Logistic Regression. The first finding indicates that there is a significant negative relationship between ownership concentration and firm performance. The second finding shows a positive relationship between insider ownership and firm performance. The paper recommends that there is dire need to reasonably diversify shareholding as a way of attracting more skills and competencies among the shareholders that can be tapped to improve firm performance. At the same time, the managers should be protected from unnecessary direct interference by the shareholders.
\end{abstract}

Keywords: Ownership, Ghana Stock Exchange, Government, Institution

\section{INTRODUCTION}

Every firm has several ways of building its ownership. Normally the type of ownership structure a firm decides to adopt is engineered by the vision of the company. According to Kumar (2003) corporate governance is an important effort to ensure accountability and responsibility and a set of principles, which should be incorporated into every part of the organization. The ownership structure is defined by the distribution of equity with regard to votes and capital as well as the identity of the equity owners. These structures are of major importance in corporate governance because they determine the incentives of managers and thereby the economic efficiency of the corporations they manage (Jensen and Meckling, 1976). The corporate governance framework according to Imam and Malik (2007) is the widest 
control mechanism (both internal and external) since it encourages the efficient use of corporate resources and ensures accountability for the stewardship of those resources utilized. Lins (2002) further contend that corporate governance could help to align the interests of individuals, corporations and society through a fundamental ethical basis and it will fulfil the long-term strategic goal of the owners, building shareholder value and establishing a dominant market share.

According to Stulz (1999), ownership can also be formed through capitalization which can be obtained through retained earnings, loans from banks, venture capital or going public. Each of these possibilities has its own advantages and disadvantages. In finance, capital structure refers to the way a corporation finances its assets through some combination of equity, debt, or hybrid securities (www.wikipedia.com; accessed 12/01/2012). A firm's capital structure is then the composition or 'structure' of its liabilities and assets. The capital structure of a firm is actually a specific mixture of debt and equity a firm employs in financing its operation Gorton and Schmid (1996).

Every business organisation has an important decision of making returns. This decision is important since the ability of a firm to make returns in this competitive environment determines to a larger extend its ability to survive in the future. This decision also affects its capital base and the decision of either going for equity financing or debt financing. In debt financing, companies borrow money or capital and resources from external sources that are to be repaid over a period of time, usually with interest. Other factors identified by Stulz (1999) with regard to firms ownership structure included volatility in earnings, asset tangibility, dividend payout ratio and profitability are determinants of corporate capital structure decisions on the GSE.

More equity ownership by the manager may increase corporate performance because it means better alignment of the monetary incentives between the manager and other equity owners (Jensen and Meckling, 1999). More equity ownership by the manager may increase corporate performance because the managers are more capable of opposing a takeover threat from the market for corporate control and as a result, the raiders in this market will have to pay higher takeover premiums (Stulz 2001). On the other hand, Fama and Jensen (2000) content that increased ownership concentration (any kind of owner) decreases financial performance because it raises the firm's cost of capital as a result of decreased market liquidity or decreased diversification opportunities on behalf of the investor.

Stock markets are widely viewed as important, if not essential, for the functioning of modern capitalist economies. The Stock Market of Ghana (GSE) is fairly new, established in 1990. However, it is one of the best performing stock market in Africa. It is one of the seven stock markets which trade automatically in Africa and one of the best four African performing stock markets (www.databankgroup.com.gh). Additionally, listing on a Stock exchange presents many opportunities for company's values addition. The connection between ownership structure and performance is an ongoing debate in the corporate finance literature. Whilst authors like Berle and Means (2002) suggests an inverse correlation between shareholdings and firm performance, Demsetz (2001) indicated that the ownership structure of a corporation should be thought of as an endogenous outcome of decisions that reflect the influence of shareholders and of trading on the market for shares. The ownership structure whether concentrated or diffuse influences the profit-maximizing interests of shareholders and the performance of company. A huge gap exists in literature on the impact of ownership structure and a firm performance. The measure of ownership structure and whether or not the endogeneity of ownership structure affect performances of firms have not been adequately 
treated (Demsetz and Villalonga, 2001) hence the importance of this study. This study therefore investigates the pattern and variation of ownership structure of listed companies and to document empirically the relationship between firm performance and corporate governance through ownership structure.

\section{Definition and Evolution of the Stock market}

\section{LITERATURE REVIEW}

The term stock market is widely used in both academia and in the working circles. The term stock market is an abstract term used for a place where trading of a company's stock takes place. It is also used to describe the totality of all stocks, especially within a country. Importantly, there is the need to distinguish between stock market and stock exchange. A stock exchange is an entity or a corporation or a mutual organisation that brings buyers and sellers of stock together. The history of the stock market begun in the 12th century France, where the courratier de change was concerned with managing and regulating the debts of agricultural communities on behalf of banks. Since these men traders with debts, they could be called the first brokers. In the early 13th century Bruges commodities traders gathered inside the house of a man called Van der Beurse, and in 1309, they institutionalized this, but until then informal meetings were organized. After the institutionalization the house where trading was done became known as the Brugse Beurse. This idea was quickly propagated around Flanders and neighbouring countries and Beurzen and soon opened in Ghent and Amsterdam.

In the middle of the 13th century, Venetian bankers began to trade in government securities. In 1351, the Venetian government outlawed spreading rumours intended to lower the price of government funds. Bankers in Pisa, Verona, Genoa and Florence also began trading in government securities during the 14th century. This was only possible because these were independent city state not ruled by a duke but a council of influential citizens. The Dutch later started joint stock companies, which let shareholders invest in business ventures and get a share of their profits or losses. In 1602, the Dutch East India Company issued the first share on the Amsterdam stock exchange. It was the first company to issue stocks and bonds. The first stock exchange to trade continuously was the Amsterdam Beurs, in the early 17th century. The Dutch pioneered short selling, opting trading debt-equity swaps, merchant banking, unit trusts and the other speculative instruments, much as we know them. Now, there are stock markets in virtually every developed country and most developing countries, with the world's biggest market in the United State, UK, Germany, France and Japan.

\section{Capital Markets in Africa}

Over the last two decades (1990 -2007), most African economies have adopted the liberalization and privatization as a development strategy for the development of their economies. According to Kibuthu (2005), the changing attitudes towards the role of the private sector in the development of African economies have facilitated the development of the capital markets. As early as the 1990's most African countries set up stock exchanges as a precondition for the introduction of market economies under the structural adjustment programs propagated by the international monetary institutions and to facilitate the privatization of state owned enterprises (Rwelamira, 1993). As at 2002, there were eighteen securities exchanges in Africa, eleven of which began operations in the 1990s. The growth in market capitalization in Africa has been described as remarkable as more countries outside of the more advanced economies of the Maghreb region (Northern Africa) and South Africa venture into the development of their capital markets (Sheehan and Zavala 2005). The statistical data on African Stock markets excluding South Africa as presented by Sunil Benimadhu (2004) is reproduced in this study. 
Table 2.1 Statistical Data on African Stock Markets (excluding South Africa)

\begin{tabular}{|l|c|c|c|}
\hline & $\mathbf{1 9 8 8}$ & $\mathbf{1 9 9 7}$ & $\mathbf{2 0 0 2}$ \\
\hline No of Stock Exchanges & 6 & 14 & 18 \\
\hline Market Capitalization of African Stock Markets (US\$ Billion) & 5.5 & 49 & 66 \\
\hline Value traded (US\$ Billion) & 0.16 & 8.6 & 6.5 \\
\hline No of listed companies & 788 & 1180 & 1760 \\
\hline
\end{tabular}

The above information showed that the number of stock exchanges increase from six (6) to fourteen (14) between 1988 and 1997 then to eighteen (18) by 2002. Additionally, the Valued of traded in Billions of US dollars increase from 0.16 to 8.6 from 1988 to 1997 but dipped to 6.5 by 2002 .

\section{History of the Ghana Stock exchange}

The Ghana Stock Exchange (GSE) is the principal stock exchange of Ghana. The exchange was incorporated in July 1989 as a private company limited by guarantee under Ghana's Companies Code, 1963 (Act 179). The Exchange was given recognition as an authorized Stock Exchange under the Stock Exchange Act of 1971 (act 384) in October 1990, and trading on the floor of the Exchange commenced in November 1990. In April 1994, it converted into a public company limited by guarantee. The GSE is located in Accra and currently has around 35 listed companies and 2 corporate bonds (www.gse.com.gh). All types of securities can be listed. The Exchange is governed by a Council with representation from Licensed Dealing Members, Listed Companies, the banks, Insurance Companies, Money Market and the general public. The Managing Director of the Exchange is an ex-officio member. The council sets the policies of the Exchange and its functions include preventing fraud and malpractices, maintaining good order among members, regulating stock market business and granting listing.

In 1993, the GSE was the 6th best index performing emerging stock market, with a capital appreciation of $116 \%$. In 1994 it was the best index performing stock market among all the emerging markets, gaining $124.3 \%$ in its index level but the 1995's index growth was a disappointing 6.3\%, partly because of high inflation and interest rates (www.wikipedia.com). The growth of the Index for 1997 was 42\%, and at the end of 1998 it was 868.35 (www.gse.com.gh). As of October 2006 the market capitalization of the Ghana Stock Exchange was about (\$11.5bil) 111,500bil cedis and by December 31 2007, the GSE's market capitalization was 131,633.22bil cedis. In 2007 the index appreciated by 31.84\% (www.gse.com.gh). The manufacturing and brewing sectors currently dominate the exchange. A distant third is the banking sector while other listed companies fall into the insurance, mining and petroleum sectors. Most of the listed companies on the GSE are Ghanaian but there are some multinationals (www.wikipedia.com).Trading is carried on the Floor of the Exchange under the Continuous Auction Trading system (CAT). Over the counter trading is however allowed in Ashanti Goldfields Company's shares (http://www.ibrokerghana.com/index.php).

Although non-resident investors can deal in securities listed on the exchange without obtaining prior exchange control permission, there are some restrictions on portfolio investors not resident in Ghana. The current limits on all types of non-resident investor holdings (be they institutional or individual) are as follows: a single investor (i.e. one who is not a Ghanaian and who lives outside the country) is allowed to hold up to $10 \%$ of every equity. Secondly for every equity, foreign investors may hold up to a cumulative total of 74\%.The limits also exclude trade in Ashanti Goldfields shares (www.wikipedia.com). These restrictions have been abolished by the Foreign Exchange Act, 2006 (Act723). There is an 8\% withholding tax on dividend income for all investors. Capital gains on securities listed on the exchange will remain exempt from tax until 2015. The exemption of capital gains applies to all investors on the Exchange. There are 
no exchange control regulations on the remittance of original investment capital, capital gains, dividends, interest payments, returns and other related earnings (www.wikipedia.com).

\section{Challenges of Developing Stock Markets in Africa}

The political and economic decisions that were translated into legal framework for the establishment and operation of the stock exchanges were rushed in many African countries. Therefore, the exchanges have not been successful in attracting a large number of other market transactions in addition to the privatized public enterprises (Asea, 2003). Most Africa's stock exchanges have remained small, underdeveloped and illiquid operating in isolation from other markets and also having low trading volumes. Additionally, most of these stock exchanges in developing countries like Ghana have and still continue to enjoy some governmental protection. This has prevented competition by national regulations and face barriers to capital mobility because of high costs of travel and communications (Asea, 2003).

The exchanges on the continent are usually highly concentrated with the best shares being held by local pension funds, banks and insurance firms that do not want to sell because they have few alternative assets to buy with sales proceeds. Infrastructure is another big problem of the stock markets in Africa, with most of the market infrastructure being underdeveloped particularly with regard to trading, settlement and delivery as manual systems and processes dominate their operations. Furthermore, the bond markets are also relatively underdeveloped in Africa's capital markets, yet they have the potential of mobilizing significant amounts of capital. They can also give African stock exchanges a tremendous boost in turnover as bonds are usually more attractive to investors than stocks. A well-integrated and customized financial information service that provides timely and accurate information service to individuals and corporate institutions is necessary for the development of bond markets (2007 NSE Handbook).

Stringent eligibility requirements have discouraged local entrepreneurs and indigenous enterprises that wish to raise funds from capital markets. The eligibility requirements have created high barriers to potential entrants to the stock exchanges such as the numerous family owned businesses in Africa. Thus, the stock exchanges tend to operate like closed membership organizations. Limited presence of institutional investors is constraining equity demand. In addition, lack of an active role in the distribution of securities to the public by other financial institutions such as banks, venture capital funds, pension funds, building societies and insurance companies is constraining supply of equity (Asea, 2003).

Some African stock exchanges have limited institutional capacity to police and enforce rules. Most of the smaller African exchanges lack the trained manpower and experience to adequately police the modern regulatory regimes they have adopted. Consequently, enforcement actions are rare and abuses are not uncommon (Sheehan and Zavala, 2005). In addition, investors, particularly minority shareholders, lack confidence in the market as some listed companies continue to operate under poor corporate governance structures. In some stock markets, participants are subject to multiple regulators thereby causing regulatory complexities, uncertainties and increased costs of compliance with different regulatory regimes (Asea, 2003). Low savings rate in many African countries has constrained demand and supply of equity in stock markets. Poverty, war, political unrest and disease have resulted in a large portion of the African population living on less than a dollar a day thereby constraining savings. Most of the new African exchanges, apart from Johannesburg, Casablanca and Cairo securities exchanges, lack attractive and diverse types of securities to offer foreign investors. Generally, there may be only two or three corporations of interest to foreign 
investors and most of these may either be subsidiaries of major multinational corporations or recently privatized companies. Consequently fund managers choose the safer course and invest in parent companies listed nearer to home (Ibid).

\section{Theoretical literature}

There is no well-established tradition of selecting specific measures for the analysis of ownership structure performance relationship. The measure adopted by various researchers is based on the availability of information and the appropriateness of the method for the research questions. Most studies that looked at the impact of ownership concentration on performance have employed the Herfindahl index or the equity stake of several largest investors, typically the top five shareholders (Demsetz and Lehn, 1985). Most studies on developing countries, where data are limited, the equity stake of the largest shareholder (Kapelyushnikov, 2000) have been extensively used. Additionally, a survey literature shows that ownership structure and performance has been extensively measured using ownership concentration and ownership identity. By definition ownership concentration refers to the percentage of shares held by an owner relative to the total shareholding of the firm contrarily to ownership identity which refers to the actual names of major shareholders. The deficiency of using any of the methods according to Kuznetsov et al. (2001) is that, none of the approach can claim to have exhaustively analyzed the relationship between ownership structure and firm performance. The strength of ownership concentration is that it pays more attention to the ability of the owners to monitor and control managerial discretion, whilst its weakness is that it fails to take into consideration the investment preferences of the owner(s) and how they affect the priorities and strategies of the firm. Additionally, studies using ownership identity addresses the issues of risk aversion, wealth creation and shareholder value but dismally fail to pay attention to the powers to control and monitor management that are conferred by actual shareholding (Cubbin and Leech, 1983).

\section{Ownership Concentration and Corporate Performance}

The first attempt to study the effect of ownership concentration on company profitability was done by Berle and Means (1932). Since then there has been several studies and according to Cubbin and Leech (1983) such studies comparing profitability of manager-and ownercontrolled companies are often categorized by the share of the largest owner. Findings of these studies usually showed a higher rate of return in companies with concentrated ownership (Cubbin and Leech, 1983) but lacked a theoretical foundation. They neither used nor provided a theory of ownership structure and seemed to imply that shareholders could profit by rearranging their portfolios. Theoretically the ownership structure of the firm is an endogenous outcome of the competitive selection in which various cost advantages and disadvantages are balanced to arrive at an equilibrium organization of the firm (Demsetz, 1983). Traditionally, concentrated ownership has been thought to provide better monitoring incentives, and lead to superior performance (Leech and Leahy, 1991). Maher and Andersson (1999) indicated that the ownership concentration lead to extraction of private benefits by the controlling shareholders at the expense of the minority shareholders. The argument put across is that if owner-controlled firms are more profitable than manager-controlled firms, it would seem that concentrated ownership provides better monitoring which leads to better performance.

\subsubsection{Ownership Identity and Firm Performance}

Quiet a significant amount of literature on firm performance has paid much attention to the issue of shareholder identity (Shleifer and Vishny, 1997; Welch, 2000). Most sampled literature indicates that the objective functions and the costs of exercising control over managers vary substantially for different types of owners. This implies that, it is not only important to know 
how much equity a shareholder owns, but rather who this shareholder is. The reason for this is because investors differ in terms of wealth, risk aversion and the priority they attach to shareholder value relative to other goals. This is because owner preferences and investment choices are influenced by shareholder interests (Nickel, 1997; Hansmann, 1996). Additionally, conflicts of interest may arise since owners have their economic relations with the firm. For instance, a bank may play a dual role of as lenders and owners, government as regulators and owners (Thomsen and Pedersen, 1997). For each of these stakeholders, preferences regarding company strategy will involve a trade-off between the pursuit of shareholder value and other goals (Thomsen and Pedersen, 1997).

Managerial ownership seems to be the most controversial ownership form as it has ambivalent effects on firm performance and considered a tool for alignment of managerial interests with those of shareholders, while on the other hand, it promotes entrenchment of managers, which is especially costly when they do not act in the interest of shareholders (Mork et al., 1988; Stulz, 1988). Thomsen and Pedersen (2000) posit that the relationship between ownership concentration (as a proxy for shareholder control over managers) and firm performance depends on the identity of the large (controlling) shareholders. The general impact of managerial ownership on corporate performance depends on the relative strengths of the incentive alignment and entrenchment effects whilst state ownership has been regarded as inefficient and bureaucratic. Vickers and Yarrow (1988) consider the lack of incentives as the major argument against state ownership. Shapiro and Willig (1990) indicated that price policy whilst Shleifer and Vishny (1994) stated political intervention and human capital problems as some of the challenges state ownership structure influences performance. Notwithstanding these challenges state ownership of firms is not without some benefits to the society. Public enterprises help cure market failures and state control seems to be more economically desirable as a way of restoring the purchasing power of the citizenry (Atkinson and Stiglitz, 1980). Aside these benefit state firms have been empirically seen to be highly inefficient and performed poorly as compared to private ones (Megginson et al., 1994), even in pursuing public interests.

The effect of foreign ownership on firm performance has been an issue of interest to both academics and policy makers. As posited by Gorg and Greenaway (2004), the main challenging question in the international business strategy is the outcome gained from foreign ownership of firms. It is duly accepted that foreign ownership plays a crucial role in firm performance, particularly in developing and transitional economies, researchers such as Aydin et al. (2007) have concluded that, on average, multi-national enterprises have performed better than the domestically owned firms. It is therefore, not surprising that the last two decades have witnessed increased levels of foreign direct investments in the developing economies.

\section{Various ownership structure and firm performance State Ownership structure}

The ownership structure is defined by the distribution of equity with regard to votes and capital but also by the identity of the equity owners (Jensen and Meckling, 1976). This structure plays an important role in corporate governance because it determines the incentives of managers and therefore it builds up the economic efficiency of the corporations. According to Demsetz (1983) since there are many successful public companies with diverse share-ownership, then there must be offsetting benefits. Omran, Bolbolc and Fatheldinc (2007) indicated in their study of Egypt that private companies have better performance than the state-owned firms whilst La Porta, Lopezde-Silanes, Shleifer (1998) stated that Italian corporate governance regime exhibits low legal protection for investors and poor legal 
enforcement. Because of these institutional characteristics, private benefits of control are high (Zingales, Luigi, 1994), and minority shareholders are usually expropriated and Grygorenko (2001) show that private companies create a better firm performance than state owned firms.

\section{The Majority Shareholders}

By majority shareholder the study refers to a single shareholder who controls more than half of a corporation's shares, or sometimes, one of a small group of shareholders who collectively control more than half of a corporation's outstanding shares. Nickel, Nicolistsas and Dryden (1997) posited that firm performance is positively related to the majority shareholder. This is because firm performance and majority shareholder are substitutable. This is contrarily to Januszeski et al (1999) who indicated that a majority shareholder has a negative influence on firm performance. Their reasons being that firms have single ultimate owner, which operate under strong ownership, experience higher productivity growth. Moreover, this effect is grown up by stronger product market competition (Januszewski et al., 2000). This competition lead to a positive effect which affect productivity growth rate by majority shareholder, but this result was economically weak.

\section{Manager Ownership}

Morck, Shleifer and Vishny, (1998) studied and analyzed the relationship between the managers' percentage shares and corporate financial performance. They gave a positive relationship for holding within three ranges, from $0 \%$ to $5 \%$, beyond $25 \%$, but negative one between 5\% and 25\%. From his thesis, Ngoc (2007) showed that the relationship between manager ownership and firm performance was inverse U-shape and Tobin's Q, with the inflection point is from $40 \%$ to $50 \%$. There was a positive relationship in holding between nonbanking financial institution and firm performance (McConnell and Servaes, 1995). Short and Keasy (1999) conducted in Great Britain for 1998 to 1992 and used two measure methods: accounting measure (return on shareholder's equity) and market measure (like Tobin's Q). They found that a positive relationship between managerial ownership and firm performance from $0 \%$ to $16 \%$ (0\% to $13 \%$ in market measure), beyond $42 \%$ and is negative from $16 \%$ to 42 $\%$ (from $13 \%$ to $42 \%$ in market measure). From all the research, it can be seen that the positive relationship between Tobin's Q and larger managers' shareholdings, better applied to small than to large firms.

\section{Assumptions on Ownership Structure and Performance of Firms}

In most studies, ownership structure and corporate governance are used intertwine hence this study also follows similar line of argument. It is usually assumed that corporate governance significantly influences corporate performance. Even though corporate performance in general is less extreme, the effect of firm ownership and control on the firm's performance has been widely discussed since Berle and Means (1932) first used it. Performance is an economic and empirical term widely used in business making literature abound. Literature on firm performance and ownership structure used for this study are classified into:

\section{Neutrality}

According to Demsetz (1983) corporate performance depends on environmental constraints; it has nothing to do with the ownership structure. For Demsetz (1983) all structures are equal. So performance has no relationship with the ownership structure and it is dependent on internal and external environment. The assumption that ownership structure has no influence over a firm's performance is referred to as the "neutrality assumption". 


\section{Convergence in interest}

Under this assumption, the greater the managerial ownership, the less inclined the managers are to divert resources away from value maximization. In other words, higher ownership by managers aligns the interest of the managers with that of the company. In other words, the greater the managerial ownership (i.e. larger the percentage of shares held by the directors of the company), the better will be the company's performance.

\section{Entrenchment}

According to this assumption, the greater the percentage of shares held by the managers, the lesser the other shareholders can compel them to manage the firm in their (other stakeholders') interests. The managers may seek entrenchment by weakening the mechanisms able to control or replace them (Charreaux, 1997). Numerous empirical studies have tried to highlight the relationship between ownership structure and corporate performance. The results are sometimes contradictory. Some works showed a linear relation (Cole and Mehran, 1998) whereas other studies highlighted a non-linear relation (Morck et al., 1988; McConnell and Servaes, 1990; 1995; Kole, 1995; Short and Keasey, 1999). For a study of this nature to have a firm foundation, it is necessary to choose variables that are quantifiable and comparable. This study has therefore chosen four variables of performance that meet these two qualifications. The chosen variables are Tobin's Q, Maris Ratio, Return on Equity (ROE), and Return on investment (ROI).

\section{Research Design}

\section{METHODOLOGY}

This research is an ex-post facto design in the sense that the researcher does not have direct control over the independent variables because their manifestations have already occurred or because they are inherently not manipulable. Ex Post Facto design provides an alternative to investigate how independent variables affect dependent variables and enables the researcher observe the independent variables after the event.

\section{Sample Technique and Sample Size}

The study adopted the purposive sampling technique. Purposive sampling which is also called deliberate sampling or judgment sampling (Gupata, 1993). According to Marlow (2001) purposive sampling allows the researcher to handpick the sample according to the nature of the research problem and the phenomenon under study. Whilst Shaughnessy and Zechmeiserter (1990) further commented that purposive method is adopted when the respondents are selected or judged to have certain characteristics or more commonly those who are likely to provide the most useful information for the purpose for which the study is being done. The sample of the study involved only financial institutions listed on the GSE.

\section{Population and Sample Size}

The target population for the study comprised of all companies listed on the Ghana stock exchange. Out of this sample, only financial companies listed on the Ghana stock exchange are used for this study. This sample is made up of Cal Bank, HFC, Ecobank Ghana Limited, Ghana Commercial Bank, SG-SSB, Standard Chartered Bank.

\section{Model Specialization}

The relationship between ownership structure and firm performance was conceptualized based on pertinent literature on corporate governance. Ownership Structure was conceptualized as comprising ownership concentration and ownership identity. Ownership concentration (shareholding above $30 \%$ ) was determined using Herfindahl Index, or the equity stake of several largest investors, 
typically the top five shareholders (Demsetz and Lehn, 1985). Four ownership categories were identified, namely: foreign; institutional; government; and diverse. Each of these ownership identities has different risk-taking orientations, which in effect impact investment decisions and firm performance differently. The data in this study were analyzed using Pearson's Product Moment Correlation and Logistic Regression. The results were presented in two categories: 1) ownership concentration and firm performance, and 2) ownership identity and firm performance.

In this research, in order to recognize the relation between independent and dependent variables, the regression was used and an equation was formed through it the influence of the independent variable on the dependent variable was evaluated.

The general form of the models used was:

$F P=b_{1} O W N C O N C+b_{2} C O R P O W N+b_{3} F O R E N O W N+b_{4} I N S T O W N+b_{5}$ GOVOWN $+b_{6} D I V O W N+b_{7} M A N O W N+b_{8}$ MANDISC

Where:

OWNCONC- Ownership Concentration; FORENOWN-Foreign Ownership; CORPOWNOwnership by Corporations; MANOWN-Ownership by Managers; GOVOWN-Ownership by Government; DIVOWN-Diverse Ownership; MANDISC-Managerial Discretion.

\section{Measuring Corporate Performance}

This study used Return on Assets (ROA), Return on Equity (ROE), and Dividend Yield (DY) to measure firm performance. These measures of firm performance have been used extensively in research in corporate governance (Xu and Wang, 1997; Milgrom and Roberts, 2000; Kennon, 2005).

\section{Research Hypothesis}

The paper seeks to test these hypotheses:

There is a positive relationship between ownership concentration and firm performance. Hypothesis $\mathrm{H}_{2 \mathrm{a}}$ : Manager (Insider) Ownership has a positive effect on firm performance. Hypothesis $\mathrm{H}_{2 \mathrm{~b}}$ : Government ownership has a negative effect on firm performance.

Hypothesis $\mathrm{H}_{2 \mathrm{c}}$ : Ownership by Corporations has a positive effect on firm performance.

Hypothesis $\mathrm{H}_{2 \mathrm{~d}}$ : Diffuse (Diverse) ownership has a negative effect on firm performance.

Hypothesis $\mathrm{H}_{2 \mathrm{e}}$ : Foreign Ownership has a positive effect on firm performance.

\section{Data Source}

The main aim of the paper is to measure how the ownership structure affects the performance of companies listed on the Ghana stock exchange. Annual data was used in the estimations of the model. To measure this performance data was source from two main sources. The balance sheet and income statement information was gotten from the various annual reports of the various financial companies used for the study. Information about ownership and control were gotten from the Ghana stock exchanges.

\section{Type of Data}

The study made used of secondary data. According to the type of data and available statistical analysis methods, in this research, the "panel data" method was used. This is because in order to investigate the relationship between ownership structure and corporate performance, dependent and independent variables investigated from two different aspects. On one hand, these variables are testing among the different companies and on the other hand, in the period of 2008 to 2012. 


\section{RESULTS AND DISCUSSION}

Table: 4.1 Descriptive Statistics of Data

\begin{tabular}{|l|c|c|c|c|}
\hline & ROI & ROE & Q & MARRIS \\
\hline Mean & 0.07 & 0.09 & 1.88 & 4.18 \\
\hline Median & 0.08 & 0.14 & 1.74 & 2.86 \\
\hline Kurtosis & 12.545 & 128.974 & 4.624 & 121.174 \\
\hline Skewness & -2.394 & -10.510 & 2.098 & 9.961 \\
\hline SE of mean & 0.003 & 0.037 & 0.041 & 0.217 \\
\hline
\end{tabular}

Table 4.1 gives some important results to comment. First of all, the results indicate that the Marris measure of performance and ownership structure was the highest among all the variables used to measure performance and ownership. Since the Marris ratio which is a permanent valuation indicator of the firm is greater than one (1) it shows that capable of creating value both present and in the future. Additionally since the data is skewed to the right (that is it is positive), it means that there is a positive growth potential of the institutions used for the study. Additionally, the Tobin $Q$ ratio which is also a measure of performance indicates that the firm has growth opportunities and that the level of investment maximizes the value and performances of the firm. The mean ROE for the financial institution used for the study is less than $15 \%$ that is, it is around $9 \%$ which shows that the company does not efficiently utilized investment funds well to generate earnings growth.

\section{Linear and Logistic Regression of the various Measures of performances}

As indicated earlier on performance used for the study was measured using three main indicators, return on asset (ROA), return on equity (ROE) and dividend yield (DY). The result of the model is presented in table 4.2 below

Table 4.2: Linear and Logistic Regression of the various Measures of performances

\begin{tabular}{|l|c|c|c|}
\hline \multicolumn{1}{|c|}{ Indicator Variable } & ROA & ROE & DY \\
\hline Predictor Variable & $\begin{array}{c}\text { Parameter Estimates } \\
(\boldsymbol{\beta})\end{array}$ & $\begin{array}{c}\text { Parameter Estimates } \\
(\boldsymbol{\beta})\end{array}$ & $\begin{array}{c}\text { Parameter Estimates } \\
(\boldsymbol{\beta})\end{array}$ \\
\hline Ownership Concentration & & -0.645 & -0.888 \\
\hline Ownership concentration & -0.761 & $1.218^{*}$ & $1.592^{*}$ \\
\hline Ownership Identity & & 0.775 & 0.826 \\
\hline Foreign ownership & $1.598^{*}$ & -0.616 & -0.483 \\
\hline Institution ownership & $1.012^{*}$ & $0.789^{*}$ & 0.723 \\
\hline Government ownership & -0.798 & & -0.111 \\
\hline Diverse ownership & $0.946^{*}$ & $-0.237^{*}$ & \\
\hline Board Effectiveness & & & 0.241 \\
\hline Board effectiveness & $-0.557^{*}$ & 0.792 & \\
\hline Manager Ownership & & & \\
\hline $\begin{array}{l}\text { Manager/insider } \\
\text { ownership }\end{array}$ & 1.003 & & \\
\hline
\end{tabular}

$* \mathrm{p}<0.05$

From the table above linear regression results shows that the dependent variable Return on Assets had a co-efficient $(\beta)$ of -0.761 and was significant at $5 \%$ significance level; Return on Equity recorded a co-efficient $(\beta)$ of -0.645 and was significant at $5 \%$ and Dividend Yield showed a co-efficient $(\beta)$ of -0.888 and a 0.05 significant level. The results of the Linear Regression presented in table 2 generally shows that, ownership concentration was negatively and significantly related to all the three indicators of performance measure (ROA, ROE and DY) which was manifested from the beta coefficients and levels of significance of the relationships. 
This means that all the dependent variables recorded significant negative correlations with ownership concentration.

Additionally, in the ownership identity, government ownership recorded negative co-efficient $(\beta)$ in all the dependent variables. The negative dependent variables shows that ROA (-0.798) was the highest followed by ROE $(-0.616)$ and DY $(-0.483)$. The entire government ownership variables were significant at $5 \%$ significant level.

Table 4.3: Logistic Regression Results for the effects of Predictor Variables on Firm Performance (Above Market Average)

\begin{tabular}{|l|l|l|l|}
\hline Indicator Variable & $\begin{array}{l}\text { Column 1 ROA Above } \\
\text { Market Average }\end{array}$ & $\begin{array}{l}\text { Column 2 ROE Above } \\
\text { Market Average }\end{array}$ & $\begin{array}{l}\text { Column 3 DY Above } \\
\text { Market Average }\end{array}$ \\
\hline Predictor Variable & Parameter Estimates $(\beta)$ & Parameter Estimates $(\beta)$ & Parameter Estimates $(\beta)$ \\
\hline $\begin{array}{l}\text { Ownership } \\
\text { Concentration }\end{array}$ & $-0.360^{*}$ & -0.085 & $-0.102^{*}$ \\
\hline Foreign ownership & $6.436^{*}$ & 3.810 & 6.579 \\
\hline Institution ownership & 4.888 & 2.595 & 3.120 \\
\hline $\begin{array}{l}\text { Government } \\
\text { ownership }\end{array}$ & -15.794 & -17.778 & -17.021 \\
\hline Diverse ownership & $6.041^{*}$ & 5.038 & 3.718 \\
\hline Board effectiveness & -0.033 & -0.042 & -0.035 \\
\hline $\begin{array}{l}\text { Manager/ insider } \\
\text { ownership }\end{array}$ & 5.013 & 4.049 & 5.162 \\
\hline
\end{tabular}

$* p<0.05$

In testing the first hypothesis that there is a positive relationship between ownership concentration and firm performance the Logistic Regression test was carried out. The result as indicated in table 3 shows that that there is a negative and significant correlation between ownership concentration and Return on Assets $(\beta=-0.360, p<0.05)$ as well as Return on Equity $(\beta=-.085, p<0.05)$. The results for Dividend Yield $(\beta=-.102, p<0.05)$ were also negative but not significant. This meant that the first hypothesis should be rejected.

In measuring the second hypothesis that Manager (Insider) Ownership has a positive effect on firm performance a Linear Regression test was ran. In that model the Pearson correlation on Return on asset yielded a co-efficient of 0.026 and was significant at $5 \%$; the returned on equity has yielded a correlation of co-efficient of 0.038 and was significant at 5\%; and DY"s correlation was 0.041 and was also significant at 5\%. Additionally, the Logistic Regression results for the three measure of performance indicate that the ROA had a co-efficient of 5.013, ROE was 4.409, and DY"s co-efficient was 5.162. All the measures were significant at 0.05. From the above therefore the study accepts the second hypothesis that there is positive and significant relationship between Manager (Insider) Ownership has a positive effect on firm performance.

The third hypothesis that "Government ownership has a negative effect on firm performance" was accepted. The reason for accepting the hypothesis is because the co-efficient of all the Logistic Regression results showed a negative co-efficient (ROA: $\beta=-15.794$; ROE: $\beta=-17.778$; and DY $(\beta)=17.021)$. The relationship was negative and significant hence the acceptance of the hypothesis.

In measuring the fourth hypothesis, the linear regression yielded the following results: the ROA had a Pearson correlation co-efficient of 0.016, ROE was -0.014 and DY -0.029 and were all less than the 5\% probability. Additionally, the Logistic Regression as indicated in table 3 
shows that ROE $(\beta=2.595, p<0.05)$, ROA $(\beta=4.888, p<0.05)$, and DY $(\beta=3.120, p<0.05)$.The above Logistic Regression are positive and significant hence the acceptance of the hypothesis "Ownership by Corporations has a positive effect on firm performance". In assessing the hypothesis that diverse ownership has a negative effect on firm performance, the return on asset had a co-efficient $(\beta)$ of 6.041 , the return on equity also had a co-efficient $(\beta)$ of 5.038 and the dividend yield co-efficient $(\beta)$ was 3.718. These co-efficient were all measured at $5 \%$ significant level. Since the co-efficient were all positives the study rejected the hypothesis diverse ownership has a negative effect on firm performance. Finally, the hypothesis Foreign Ownership has a positive effect on firm performance was accepted. This is because the Logistic Regression results were ROA $(\beta=6.436, p<0.05)$, ROE $(\beta=3.810, p<0.05$; DY $(\beta=6.579, p<0.05)$ while that Linear Regression results were ROA $(r=0.044, p<0.05)$, ROE $(r=.037, p<0.05)$; DY $(\mathrm{r}=.041, \mathrm{p}<0.05)$.

The first findings show that there is a significant negative relationship between ownership concentration and firm performance. This is because according to some school of thoughts the free-rider problems associated with diffuse ownership do not arise with concentrated ownership, since the majority shareholder captures most of the benefits associated with this monitoring (Ongore, 2011). The study found the opposite to be the case for financial institutions listed on the Ghana stock exchange. The reason for the above is because more than 25 per cent of shares are concentrated on a few hands (i.e. five shareholders or less), hence the tendency for the shareholders to be rabid in their monitoring, controlling and ratification roles. This stifles managers' creativity and innovation, and ultimately affects firm performance adversely. It is even worse when the shareholders lack specific and general knowledge about the business of the firm (Ongore, 2011).

The second hypothesis indicates a positive relationship between insider ownership and firm performance. It has been argued by Namazi and Kermani (2008) and Short and Keasy (1999), that when managers own shares in their company, they become more committed to the organization since they have a stake in the residual income of the firm, and are likely to bear the cost of mismanagement. This commitment translates to higher performance. The study confirmed this position for listed financial companies in Ghana. Additionally, government ownership has been roundly criticized for contributing to generally poor performance of firms, due to excessive bureaucracy, tribalism, nepotism, poor human resource policies, political expediency in appointments and lack of respect for laws and regulations of the country (Shapiro and Willig, 1990); Shleifer and Vishny, 1994). This study reaffirms this long-held position hence a significant negative relationship between government ownership and firm performance.

There is a positive relationship between ownership by corporations and firm performance. This is one of the most controversial hypotheses mainly due to the differences in investment preferences and shareholders" goals (Mork et al., 1988; Stulz, 1988). This means that performance is attributable to the investment choices and orientation of the parent companies, and not necessarily the ability of managers. There is a positive relationship between diffuse ownership and firm performance. The global trend toward diverse ownership has been confused by many researchers, because it undermines the popular belief that managers are inherently self-seeking and can easily wreck the organization if left without close monitoring. The findings have brought a new dimension that emphasizes managerial discretion for creativity and innovation, and less monitoring by shareholders. Thus, diffuse ownership of firms provides a good environment for excellent policies to be developed and implemented by managers (Ongore, 2011). 
The positive and significant relationship between foreign ownership and firm performance appears to have gained universal acceptance across the globe due to a number of factors (Aydin et al., 2007). First, foreign owned companies have access to management systems whose efficacy has been tested in many contexts. The massive resource base and bail-out plans for fledgling affiliates are other factors that enhance performance of foreign owned firms (Gorg and Greenaway, 2004). However, the ability of these companies to re-organize their global operations to be able to assign more costs to harsh tax regimes and profits to tax havens in a bid to reduce their overall tax liability, is the most damning feature of foreign ownership (Ongore, 2011).

\section{CONCLUSIONS}

The conclusion that may be drawn from the study findings is that in Ghana, ownership concentration is inimical to manager creativity and innovation, and curtails firm performance. The typical agency problems that are very likely to arise in situations where professional managers control the assets of a corporation in which they are not shareholders are adverse selection (miscalculations) and moral hazard (failures of managerial integrity). It has been argued that these problems often arise because managers lack the requisite motivation to ensure prudence since they do not have a stake in the residual income of the firm (Moldoveanu \& Martin, 2001; Fama \&Jensen, 1983). According to Mork and colleagues (1988) and Stulz (1988), managerial ownership is the most controversial and ambivalent form of firm ownership, and has mixed effects on performance.

Whereas ownership by managers may be seen as a system of aligning the interests of managers with those of the shareholders in a way that enhances corporate performance, this form of ownership can also lead to entrenchment of managers, which is costly when they chose to pursue their self-interests. It has been argued that the overall impact of managerial ownership on firm performance depends on how well the entrenchment effects and incentive alignment are balanced (Cubbin and Leech, 1982; Nickel, 1997 Hill and Jones, 1982; Hansmann, 1988, 1996). The findings of this study agreed to a significant extent with the argument that managerial ownership enhances corporate performance. In Ghana, manager ownership of firms has been actualized through executive share options. The findings therefore, suggest that when managers also double up as shareholders, they are motivated to work towards realization of the wealth creation objective of the shareholders of whom they are part. On the other hand, managers who are not shareholders are more likely to engage in insider dealings as a way of enhancing their personal wealth and prestige.

There is near convergence that Government ownership of firms leads to bureaucracy and inefficiency that negatively impacts firm performance (Nickel, 1997). Many researchers (De Alessi, 1980, 1982; Vickers and Yarrow, 1988; Shapiro and Willig, 1990; Shleifer and Vishny, 1997) have argued that state-owned enterprises are political firms with citizens as the shareholders, but these citizens have no direct claim to the residual income of those firms. The citizens thus cede their ownership rights to the bureaucracy which does not have clear incentives to improve performance of the corporations. Others (Nickel et al, 1997) have attributed the prevalent poor performance of Government owned firms to the tendency of those firms not to strictly adhere to government statutory requirements and regulations. Political manipulation and poor human resource policies are other factors that have been blamed for the general poor performance of state-owned enterprises (Shapiro et al, 1990). Since the early 1990"s, the Ghana Government has pursued a deliberate policy of divestiture, aimed at reducing state ownership of corporations with a view to attracting private sector participation in management of the fledgling state corporations. It was envisaged that this policy would infuse modern management styles into the public sector that would ultimately 
improve performance of these companies. The fact that Government ownership of firms was found to still impact firm performance negatively is perhaps an indication that the divestiture program in Ghana is yet to reach a critical level where its value can begin to reflect on corporate performance.

When a firm acquires shares in another firm, the shareholders of the first firm extend their investment preferences, interests and risk taking behaviour to that new firm. The interesting thing about firm ownership by other firms in Ghana is that the holding firms are typically large corporations with the ability to reorganize their branch/affiliate operations to bail out nonperforming affiliates. Most of these holding firms have also reported good performance during the period of study. The good performance of the firms they own is therefore, consistent with the documented practice by firms to extend their investment preferences and risk-taking behaviours to the firms they acquire.

Regarding the impact of diverse ownership on firm performance, the findings of this study appear to contradict those of previous researchers (Fama and Jensen, 1983; Jensen and Meckling 1976; Berle and Mean, 1932) who have argued that agency problems are more severe in diffusely held firms due to lack of capacity to collectively monitor the activities of managers, a situation that gives managers unlimited leeway to run the affairs of the corporation in their own self-interest. This argument, however fails to appreciate that shareholder-managers will almost invariably demonstrate more commitment to the firm than will their counterparts who are not shareholders since the latter have no stake in the residual income of the firm. Although some researchers have tended to favour concentrated ownership over diverse ownership, the reality is that the agency costs incurred in monitoring managers (especially if they are not shareholders) are huge, and may undermine firm performance.

Thus, it is a lot cheaper for managers to be able to make independent decisions that support shareholder objectives than have shareholders to impose imprudent ideas on them. The import of the study findings is that in Ghana, managers work better in an environment where they are afforded an opportunity to own shares of the firm, then allowed freehand to exercise their professional judgment without undue influence from shareholders. This arrangement works best in a diffusely held firm. It can also be argued that the high performing blue chip companies have high likelihood to attract more individual investors to buy their shares, thereby diversifying shareholdings. The hypothesis $\mathrm{H}_{2} \mathrm{~d}$ is therefore, rejected on the basis of the study findings.

The most definitive results were on the relationship between foreign ownership and firm performance. The significant positive relationships have vindicated the long-held belief that on average, foreign owned companies perform better than their counterparts with dominant local ownership. Thomsen and Pedersen (1997) posit that preferences regarding company strategies will often involve a trade-off between the pursuit of shareholder values, orientation and other goals. Successful companies with an international presence tend to be large, with well-established management systems that are replicated (with minimal customization) in all their branches and affiliates abroad.

\section{Reference}

[1] Ahmardpour K., \& Krdtbar F. (2008)“Capital structures in developing countries”. Journal of Finance, 55(1): 87130.

[2] Asea J. (2003) Understanding the determinants of managerial ownership and the link between ownership and performance. Journal of Financial Economics 53: 335-384. 
[3] Berle A, Means G (2002). The Modern Corporation and Private Property. (2nd éd.) Mac Millan, New York,. p. 268.

[4] Brown,L. D.,Caylor, M. L., 2006. “Corporate governance and firm valuation” Journal of Accounting and Public Policy 25, 409-434.

[5] Charreaux G (1997). Corporate governance, corporate governance theories and facts, Economica, Paris, p. 539.

[6] Cole D. and Melran, M (2004) What do we know about capital structure: Some evidence from international data". Journal of Finance, 50: 1421-60

[7] Cornett, M.M.,Marcus . A .J ., saunders , A. , Tehranian , H. , 2007 . "The impact of institutional ownership on corporate operating performance" Journal of Banking \& Finance

[8] Cubbin S. and Leech N. (1983) “Determinants of enterprise performance

[9] Daryayi,A,(2009), The effect of corporate governance on market value share ratio...on Tehran stock exchange " master thesis of Mazandaran University Iran.

[10] Demsetz H and Lehn K (1983), "The Structure of Corporate Ownership: Causes and Consequences”, Journal of Political Economy, Vol. 93, No. 6, pp. 1155-1177

[11] Demsetz, H., Villanonga, B. (2001). Ownership Structure and Corporate Performance. Journal of Corporate Finance, 7,209-233.

[12] Ezazi,M.S., Sadeghisharif,S.J., Alipour,M., Amjadi,H., (2011). "The Effect of Ownership Structure on Share Price Volatility of Listed Companies in Tehran Stock Exchange: An Empirical Evidence of Iran" .International journal of business and social science. Vol. 2 No.5163-169.

[13] Fama T. and Jensen M. (200) "An empirical analysis of the determinants of corporate debt ownership structure”. Journal of Financial and Quantitative Analysis, 32: 47-69.

[14] Gorg H. and Greenway T. (2004) Founding family control and capital structure: The risk of loss of control and the aversion to debt". Entrepreneurial Theory and Practice, 23: 53-64.

[15] Gorton G. and Schmid F. (1996) Universal Banking and the Performance of German firms. Journal of Financial Economics 58: 29-80.

[16] Grygorenko F. (2001) What Managers Think of Capital Structure Theory: A Survey. Financial Management, Winter, pp. 82-91.

[17] Imam M. O. and Mahfuja Malik, 2007, "Firm Performance and Corporate Governance through Ownership Structure: Evidence from Bangladesh Stock Market” Working Paper 2006-01, Center for Corporate Governance and Finance Studies, University of Dhaka.

[18] Jensen, M and Meckling, W, 1976. Theory of the firm: managerial behavior, agency costs, and ownership structure. Journal of Financial Economics 3, 305-360.

[19] Karami,Gh,(2008)The review of relationship between the final owners and the concept of gain information, Auditing Review Journal Vol,9

[20] Kaserer Christoph, and Benjamin Moldenhauer, (2005), "Insider Ownership and Corporate Performance Evidence from Germany”, Working Paper", Centre for Entrepreneurial and Financial Studies (CEFS) and Department for Financial Management and Capital Market

[21] Kibuthu A. (2005) The determinants of corporate liquidity: Theory and evidence". Journal of Financial and Quantitative Analysis, 33: 335-59

[22] Megginso et al. (1994) Small firm growth, access to capital markets and financial structure: Review of issues and an empirical investigation". Small Business Economics, 8: 59-67.

[23] Sunil Benimadhu (2004) „An Investigation on the Relationship between Capital Structure and Corporate Performance of Firms in the Financial and Consumer Product During and After Financial Crisis. MBA Project Paper.

[24] Kumar Jayesh, (2003). “Ownership Structure and Corporate Firm Performance”, Indira Gandhi Institute of Development Research, Working paper. 
[25] Lehmann Erik, and Jürgen Weigand, (2000), “Does the Governed Corporation Perform Better? Governance Structures and Corporate Performance in Germany", Working Paper, Department of Economics, University of Konstanz

[26] Lemmon, M. and Lins, K.L 2003, “Ownership Structure, Corporate Governance and Firm Value: Evidence from the East Asian Financial Crisis" The Journal of Finance, Vol LVIII No. 4, August 2004

[27] Marlow R. (2001) A method of inclusion probability proportional to size selection. Statistics, 49(2), 277-281

[28] McConnell, J. and Servaes, C. (1995). Additional evidence on equity ownership and corporate value. Journal of Financial Economics 27, 595-612

[29] Andesson A. (1999) Corporate capital expenditure decisions and the market value of firms. Journal of Financial Economics, 14, pp. 399-422.

[30] Morck, R, Shleifer, A, and Vishny, R, 1988. Management Ownership and Market Valuation: An Empirical Analysis, Journal of Financial Economic 20, 293-315.

[31] Morck, R., Shleifer, A., Vishny, R., and Stulz, F. (1988). Management Ownership and Market Valuation: An Empirical Analysis, Journal of Financial Economics 20, 293-315.

[32] Mueller, E. and A. Spitz (2006). "Managerial Ownership and Company Performance in German Small and Medium-Sized Private Enterprises. “German Economic Review. Issue 2, pp. 2-18.

[33] Ngoc D. (2007)Corporate ownership structure and performance. The case of Management Buyouts. Journal of Financial Economics, 27, pp.143-164.

[34] Nickel N., and Dryden, C. (1997) The effect of capital structure on a firm "s liquidation decisions". Journal of Financial Economics, 13: 137-51

[35] Kerman.M, A, (2008) The effect of ownership structure on the performance of accepted companies in Tehran stock Exchange" Auditing Review Journal Vol,8 Iran azi.

[36] La Porta R, F. Lopez-de-Silanes, A. Shleifer, and R.W. Vishny, 2000, Agency Problems and Dividend Policies around the world, Journal of Finance 55(1):1-33.

[37] Lauterbach B. and Tolkowsky E. (2004) Market Value Maximizing Ownership Structure when Investor Protection is Weak", Discussion Paper No. 8-200.।

[38] Lins, K, (2002), Equity Ownership and Firm Value in Emerging Markets, Working paper, University of Utah.

[39] Sadeghi Sharif, S, J. Bahadori, H. (2009)The effect of structural ... on Tehran stock exchange" Financial Research Journal,Summer-Spring,pp61-80.

[40] Shapiro C. and Willig R. (1990) "information-theoretic" perspective to explain the economic rationale for privatization, Journal of Economic perspective Vol. 22 pp13

[41] Shaughnessy, J.J. \& Zechmeister, E.B. (1990) Research methods in psychology, McGraw-Hill: New York.

[42] Gupta V. (1993) Robustness of some designs against missing data. J. Applied Statist, 18, 303308.

[43] Shleifer, A and Vishny, R, 1997. A survey of corporate governance. Journal of Finance 52, 737 -783.

[44] Short A, and Keasy T. (1999) How SME uniqueness affects capital structure: Evidence from a 1994-1998 Spanish data panel". Small Business Economics, 25: 447-57.

[45] Sheehan S. and Zavala 0. (2005) The economics of small business finance: The roles of private equity and debt markets in the financial growth cycle". Journal of Banking and Finance, 22: 613-73

[46] Thomsen, s., Pedersen, t., 2000. "Ownership structure and economic performance in the largest European companies. Journal of strategic management, 21, 689-705 United Nations Development Program (2003),

[47] Vickers F., and Yarrow J. (1999)Ownership Structure, Corporate Governance and Firm Value: Evidence from the East Asian Financial Crisis" The Journal of Finance,

[48] Zingales L. (1994) The value relevance of nonfinancial information: A discussion. Journal of Accounting and Economics 22: 31-42. 